\title{
WHAT'S THE BIG IDEA? MEDICAL STUDENTS AND PROFESSIONAL VALUES
}

\author{
Andrew Smith, Consultant Anaesthetist \\ Royal Lancaster Infirmary
}

\begin{abstract}
Jaded Health Service (52) seeks young doctors for mutually satisfying relationship. Me: suffering from reorganisation fatigue, jilted by one Health Minister after another (can any man deliver what he promises?), soldiering on. You: kindly, approachable, sceptical but not cynical, resilient in the face of change, tolerant of ambiguity, eager to learn and grow. Speciality immaterial. Come and be the jewel in my crown.
\end{abstract}

We stand on the edge of a great opportunity - to be involved, more closely than ever before, with young people as they develop into the doctors of the future. The bundle of loosely-related prejudices that follows is bound by two premises. The first is that we have a great deal to offer. The second is that we can benefit too. I believe that this offers us the chance, as members of a profession under siege, to reclaim our future for ourselves as well as for the doctors who follow us.

\section{CHANGING TIMES}

The General Medical Council's booklet Tomorrow's Doctors ${ }^{(1)}$ heralded a sea-change in undergraduate medical education. It had been recognised that medical training was irrelevant to the needs of society now, let alone in 30 years' time, when those doctors now in training will still be practising. The GMC recommended curricular change - for instance, less compulsory material, more scope to pursue individual interests, and a shift in focus to allow primary care to host much more educational activity than previously. They suggested broader recruitment, encouraging graduates from other disciplines and those who may have followed unconventional paths to apply. In theory such diversity should enrich the practice of medicine, but whether we will actually see fewer chubby-cheeked public schoolboys from the shires and more mature students from other walks of life is anybody's guess. Perhaps more importantly for us, there was an implicit acknowledgment that not only was medical education failing patients, it was also not equipping doctors properly for the complex world of modern practice.

Something is clearly wrong with medicine. How can you explain the dissatisfaction of many newly-qualified doctors? How can you explain the falling number of sixth-formers considering a career in medicine? How have we allowed our world to evolve to the point where doctors and managers witness aberrations in clinical practice, for instance in Bristol and Alder Hey, and do nothing until it is too late? We have lost our way as a profession and risk ceding our self-regulatory powers to others. We cannot help communicate this collective loss of nerve to the emerging generation of doctors. To return to the 'lonely hearts' theme, it's said that if you want to see how your wife might be in thirty years' time, you need only look at her mother. Do medical students and junior doctors look at their seniors and see the image of their future selves? If they don't fancy ending up cankered, secretive, arrogant and embittered, it's no wonder they call the relationship off. We need to re-establish our guiding values and principles, and I suggest that preparing ourselves for transmitting them to others is one of the finest ways of doing so.

Fish and Coles, in their book Developing Professional Judgment in Health Care ${ }^{(2)}$, argue that one of the difficulties which professionals face is that much of our work - diagnostic reasoning, clinical acumen and professional judgment - is intuitive and hard to explain. They maintain that we are unable to articulate our professionalism, and at a time when we are being challenged to account for our actions and the judgments that lie at the base of them, we seem grossly unprepared to give an account of them. Learning to communicate this aspect of practice to doctors in training should help us as much as it helps them.

\section{A MORECAMBE BAY 'STYLE'?}

I believe that the writing is on the wall for the traditional city-centre teaching hospital. The focus of undergraduate medical education is shifting into primary care, and the recommendations of the recent Clarke report ${ }^{(3)}$ into $\mathrm{R} \& \mathrm{D}$ in the health service also look set to spread research activity more evenly throughout the service. District general hospitals have often scored highly amongst students for many reasons. For a start, there are relatively fewer students than in larger institutions, so there is less competition for patients and teaching. Smaller hospitals are friendlier, and the food and accommodation are often better. Also, because we are unencumbered by the baggage of long-existing teaching centres, we have the freedom to create afresh our own 'brand' of institution.

How much scope will there be for developing our own individual ethos, a true 'Morecambe Bay style'? Clearly not much in the content and organisation of modules, which will be determined in Liverpool, but there will be some areas where we will be able to guide matters.

Casting around for a framework to support my developing notions, I came across Harden's booklet on curriculum planning ${ }^{(4)}$. He describes eight traditional approaches, each emphasising a different aspect. They are:

- content ('cookbook approach')

- aims and objectives ('engineering approach')

- teaching methods ('mechanics approach')

- timetable ('railway approach')

- problems with the existing curriculum ('detective approach')

- one educational idea or strategy ('religious approach')

- rules and regulations of the school ('bureaucratic approach')

- a curriculum designed to enhance the public image of the institution ('public relations approach'). 
Traditional educational curricula were defined overwhelmingly in terms of content but this is now out of fashion. Problem-based teaching is all the rage at present, though you might quibble that medical practice is less about solving problems than managing insoluble ones. (Who was it who said that the definition of a professional is someone who has to make decisions based on inadequate information?). Thought-provoking though Harden's classification is, it still focuses on the process of curriculum design rather than the end product. So, rather than looking at structures, I will shift to outcomes and pose the question:

\section{WHAT SORT OF PERSON DO WE WANT TO END UP WITH?}

Or, put another way, what qualities and values would we wish for in our future colleagues? If we can fix on these, it should be possible to gear our teaching behaviour to foster them, no matter what specific subject matter we use as a vehicle. Everyone is likely to have their own 'top ten' list of virtues and characteristics, and mine appear in the 'ad' at the head of this article. As part of a search for excellence in trainee GPs, Neighbour ${ }^{(5)}$ surveyed their trainers for what they considered to be the hallmarks of excellence in their apprentices. His main findings are summarised in the figure below.

\begin{tabular}{|c|l|}
\hline response to novelty & $\begin{array}{l}\text { a positive and welcoming response to new } \\
\text { ideas and methods }\end{array}$ \\
\hline 'caritas' & $\begin{array}{l}\text { embracing compassion, sensitivity, } \\
\text { approachability and relating to all social } \\
\text { classes }\end{array}$ \\
\hline clinical competence & $\begin{array}{l}\text { sound, reliable clinical skills and keeps up to } \\
\text { date }\end{array}$ \\
\hline self-awareness & $\begin{array}{l}\text { aware of own strengths, weaknesses and } \\
\text { educational needs; familiar with own } \\
\text { psychological 'landscape' }\end{array}$ \\
\hline group ability & $\begin{array}{l}\text { refers to performance in small group work as } \\
\text { well as teamwork and leadership }\end{array}$ \\
\hline personal qualities & $\begin{array}{l}\text { affability, sense of humour, maturity, } \\
\text { conscientious etc }\end{array}$ \\
\hline educability & $\begin{array}{l}\text { self-questioning, willing to change, the ability } \\
\text { to grasp and benefit from educational } \\
\text { opportunities }\end{array}$ \\
\hline mission & $\begin{array}{l}\text { having a clear and detailed vision of what } \\
\text { one wants out of life }\end{array}$ \\
\hline
\end{tabular}

Hallmarks of excellence in trainee GPS

Very few of these appear in the curricula of medical schools. This is no surprise, as they are nebulous, slippery and hard to quantify. However, they are at the very heart of what it means to be a doctor. This is one reason we need to spend time in self-examination. Answering such questions for ourselves as 'Why did you choose medicine as a career?', 'Who were your most influential teachers, and why?' and 'What guides and sustains your practice?' can help us explore these issues more deeply.

\section{WHO SHOULD TEACH THE STUDENTS?}

Anyone and everyone? Or just the chosen few? (I would favour the latter, but the question is - who will do the choosing?) Do you like having students around? Do you enjoy the company of vigorous, lively-minded young people? If not, or if you find that they're neither vigorous nor lively-minded when you're teaching them, then it may be time to concentrate your energies elsewhere. Traditional medical academic career paths have tended to sideline teaching, with reward and promotion depending more on research. Formal academic posts may be inappropriate for those who don't intend to pursue much research, but the American term 'clinician-educator' may point the way to an alternative. Naturally, we will need an identified 'faculty' of teachers in primary care and in hospital, and time will need to be freed up for the job to be done properly, for there is too much at stake to allow it to be simply 'bolted on' to consultants' and GPs' existing commitments. I don't believe that teaching suits everyone. Chris Bulstrode, Postgraduate Dean for Oxford and Anglia and champion of downtrodden SHOs, once conducted a survey of teaching hospital consultants to see if they could identify medical students who had been attached to their 'firm'. Many were unable to give their students' first or last names, nor come up with one piece of information which could distinguish them as individuals from primitive rota-fodder. The BMA student membership subsequently went so far as to suggest that students should longer be allocated to these consultants. What's more, in today's student-evaluated climate, a teacher who doesn't deliver what students think he should is likely to be dropped swiftly from the faculty.

\section{HOW CAN WE TEACH THEM?}

It is likely that any doctor who intends to do more than occasional teaching will have to undergo formal training in educational methods and appraisal. Courses are already run by the Postgraduate Dean for this purpose. But whilst these may be useful in offering a menu of styles and formats, these may not be all we need. Mission, purpose, curiosity, judgement, compassion and the like, don't lend themselves to formal instruction. Teaching by example is one of the most powerful tools we have (remember your role models from medical school?) but may also have its limits. Neighbours's book offers the most appropriate method I have seen for bringing out professionalism. It draws together an eclectic range of influences including Socratic dialogue and sports coaching to detail what he terms 'awareness-centred learning'. At the heart of this method is trust, the conviction that students want to learn and develop, and only need to be given the right opportunity at the right time. The teacher's job is to recognise the students' need, heighten their awareness of the gap in their knowledge, and lead them to filling it. Our students will have within themselves values, beliefs and principles. We need to trust that the future is in their hands, and encourage them. As the iconoclastic director Jonathan Miller, himself a doctor, has observed: 'Really talented directing is simply reminding the actors of things they knew all along, but had forgotten'. And, just as I hope that our students will be in some small way inspired by us, I hope too that they will remind us of what first inspired and energised us before we were caught up in the humdrum and hurly-burly of clinical practice.

\section{REFERENCES}

1 General Medical Council Tomorrow's Doctors: Recommendations for Change in Undergraduate Medical Education London: GMC, 1993

2 Fish D, Coles C Developing Professional Judgment in Health Care Oxford: Butterworth-Heinemann, 1998

3 Report of strategic review of the NHS R\&D levy. London: 2000

4 Harden RM (1986). ASME Medical Education Booklet No 21. Approaches to curriculum planning. Medical Education 20:458

5 Neighbour R The Inner Apprentice Newbury: Petroc Press, 1996 